\title{
An Assessment for Record Keeping and Cemetery Management: A Case of Lusaka City Council, Zambia Based on Technology Acceptance Model (TAM)
}

\author{
Barbara Chibuye, Jackson Phiri \\ Department of Computer Science, Graduate School of Business, The University of Zambia, Lusaka, Zambia \\ Email: barbaramful@gmail.com, jackson.phiri@cs.unza.zm
}

How to cite this paper: Chibuye, B., \& Phiri, J. (2022). An Assessment for Record Keeping and Cemetery Management: A Case of Lusaka City Council, Zambia Based on Technology Acceptance Model (TAM). Open Journal of Business and Management, 10, 577-590.

https://doi.org/10.4236/ojbm.2022.102032

Received: November 3, 2021

Accepted: February 11, 2022

Published: February 14, 2022

Copyright $\odot 2022$ by author(s) and Scientific Research Publishing Inc. This work is licensed under the Creative Commons Attribution International License (CC BY 4.0).

http://creativecommons.org/licenses/by/4.0/

\section{(c) (i) Open Access}

\begin{abstract}
The purpose of this study was to evaluate the factors that affect record keeping on cemetery management using the Technology Acceptance Model (TAM). The study focuses on Public Cemeteries which are managed by the municipality city council Lusaka Zambia. The study aimed to assess perceptions on adopting the electronic model for cemetery record management at Lusaka City Council (LCC). This was a cross-sectional design using descriptive quantitative approach in Lusaka District with a population of over $1,733,821$. Study stratified seven constituencies due to high population density and applied Taro Yamane formula for sample size of 313/400 (78.3\%). Researcher-Led Interviews were used and questionnaires pretested for precision and consistency. Statistical package for the social science (SPSS) software was used to report frequencies and Chi-Square to test the hypothesis. Of the 313 respondents, the study found not enough evidence to reject the null hypothesis and that electronic data management of records would affect access to cemetery services at the LCC. While access to services at LCC was statistically significant $(\mathrm{P}-\mathrm{V}=0.01)$. Similarly, the null hypothesis was rejected and it was concluded that association between perceived risks of electronic record management and Cemetery Management at LCC should migrate to the electronic management of cemetery records.
\end{abstract}

\section{Keywords}

Record Keeping, Cemetery Management, Lusaka City Council and (TAM) Model

\section{Introduction}

Currently, electronic or internet (e) governance has been adopted by a number 
of government ministries in Zambia either completely or partially or in phases. The Lusaka City Council under the Ministry of Local government and Housing is one of the ministries lagging in transitioning to e-governance particularly in managing registration information concerning cemetery management (Afla \& Reza, 2012). Access to records on cemeteries at Lusaka City Council registration has not been easy as the government is still transitioning from manual to internet governance (Mporokoso \& Phiri, 2016). However, the council still lacks a digital all-accessible registration database, making it difficult to update records, locating of burial slots and cemetery mapping. In many cultures, cemeteries are more than just a place of burial. In the rural settings, cemeteries carry spiritual, religious and cultural significance (Mporokoso \& Phiri, 2016). However, since Zambia was first inhabited, people have been burying their dead following traditional customs and practices without formal documentation of burial sites. Over the past two centuries, management of burial site documentation through registration of deaths has evolved but remained largely manual. As cities such as Lusaka continue to grow exponentially, infrastructure development to carter for the growing population takes up a lot of space. As a result planning for cemeteries becomes a challenge due to lack of space making it difficult to manage and keep accurate cemetery records. To manage volumes of records, matched record management models are required to be implemented as opposed to manual model (Grzybowski, 2012).

According to Mporokoso and Phiri (2016), cemeteries in the urban areas of Zambia like Lusaka have historically been planned, landscaped to house human remains. However, older cemeteries are running out of space for new burials, especially in major urban municipalities. This is because of rapid urbanization in towns and cities, which has resulted in fierce competition for well-located land. Municipalities on the other hand have, also been faced with the challenge of cemeteries developing informally or on land geographically unsuitable for in ground burial and more importantly shortage of burial sites.

The main challenge facing cemetery management today in Zambia is the present and future availability of land for cemeteries. As such, it is argued that there is need to use archaeological techniques in the mapping of graves, the locating of unmarked graves and in some cases the identification of unlabeled graves, and more importantly indication of cemetery grounds that are unused and ready for usage.

The situation facing them can be traced to a small revenue base and minimal institutionalization of policies and practices related to cemetery management as well as the absence of by-laws to help ensure the effective management of cemeteries (Phiri, 2015). On the other hand, rural cemeteries are not fenced, leading to vandalism and trespass by stray animals, while municipal control over cemeteries is contested and communities do not want to cede control of them (Koonce, 2011).

Despite the challenges relating to the cemetery management and identification as well as measures to make sure that the cemeteries are registered, many rural areas graves are not registered and this has affected the process of grave marking. This is effect has since raised the need for effecting an all-applicable system 
in the form of a mobile application that will help make sure that cemeteries are mapped and a tracking system for used land as well as graves open and available for public use at a fee are indicated.

Ideally there is supposed to be an adequate record management recording of deaths and cemetery management at Lusaka City Council which would make the public have access to information or records on cemeteries from the database registration department as and when they want to access the services. Presently, record keeping is management manually and the cemetery markings on the graves have disappeared on old graves and those without tomb stone or any landmark. This has made it difficult for the still living relatives to the deceased fail to locate the graves for maintenance. This also poses a challenge for the entire management of the cemetery by the Lusaka City Council to have proper maintenance of the cemeteries. As a result, the cemetery is in a deplorable state because of the poor mapping and record keeping of the cemetery hence making cemetery management a challenge.

Therefore, the study, sought to establish ways to ensure effective automated cemetery management in Zambia through a case study of Lusaka City Council. In so doing the study used the Technological Adaption Model (TAM) to establish perceptions on electronic record management for cemetery management.

The article is organized as follows; firstly, the empirical literature review which is the study done by other authors. Secondly, the theoretical background that guided the research will be outlined, then the methodology used in the study will be explained and thereafter the results of the study and the conclusion of the results. Lastly, the conclusion drawn and recommendations will be outlined, limitations of the study, acknowledgements and conflicts of interest to be declared by the author.

\section{Empirical Literature Review}

As technology is evolving, government institutions are not lagging behind. Technology is being adopted by a number of government ministries in Zambia either completely or partially in phases. The Lusaka City Council under the Ministry of Local government and Housing is one of the ministries lagging in transitioning to e-governance particularly in managing registration information concerning cemetery management (Afla \& Reza, 2012).

As technology advances significant changes in the business global economy and business environment is rapidly changing. Zambia is not exceptional to the change. However, Lusaka municipal council still lacks a digital all accessible registration database, Ngoepe (2014) made it difficult to update records and cemetery mapping. This section, therefore, discusses the effectiveness of record keeping and cemetery management and establishes the factors that affect services for the public cemeteries such as locating of tombstones, poor mapping of burial slots and managing of data records for the deceased.

Ngoepe (2014) conducted an investigation into the records management prac- 
tices and the challenges faced by traditional institutions in South Africa. The findings reviewed that although there were sporadic cases of record keeping institutions lack facilities, equipment and skilled personnel to apply correct record management to traditional institutions of local municipals.

Koonce (2011) highlighted that, cemeteries in the urban plan: opportunities and constraints it was understood that it is important within the context of city planning to better understand how cemeteries have shaped current urban forms globally. Weitman (2012) asserted that natural burial within urban cemeteries plays an important role in helping to move public acceptance towards a less intensively managed landscape and less manicured that can avoid a drastic climate change. Hence, the management needs to have a proper management system to ease the data collection process for the cemeteries. This advancement was based on understanding of the need to attempt and understand the trends of cemeteries.

In the Zambian context Mporokoso and Phiri (2016) affirms that in order to make the business more lucrative, advanced that a web portal service would be able to improve the overall productivity, increasing customer satisfaction, enhancing business responsiveness and maintaining a competitive edge because it provides simple access to let the user perform the tasks for it. Besides, it is also proven that a portal is a good tool to help manage the cemetery.

Another study conducted by Komalasari (2020) indicated that the necessity of managing the cemetery areas in cities correctly and effectively has increased the importance of the Cemetery information System (CIS). In this case, the study learn that CIS provides a fast, economical and planned decision support system by using the latest technologies for business and operations related to the management and use of cemeteries, which is one of the main offices of all municipalities. Figure 1 shows the TAM Model which shows the perceived ease of use, intention to you and usage behavior.

\section{Theoretical Framework}

First, confirm that you have the correct template for your paper size. This template has been tailored for output on the custom paper size $(21 \mathrm{~cm} \times 28.5 \mathrm{~cm})$. The study reviewed two schools of thoughts around technological transition from traditional model. The theory involved here is the theory of reasoned action

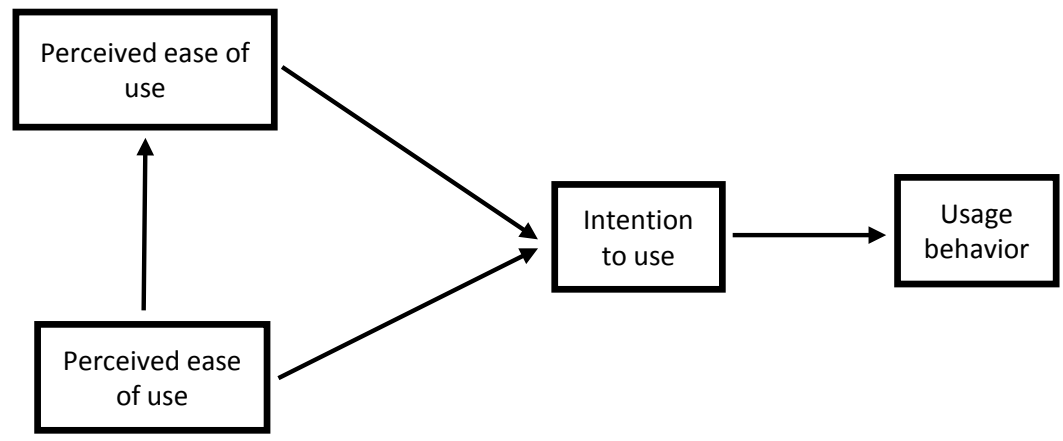

Figure 1. Technology acceptance model. Source: (Venkatesh \& Davis, 2000). 
(TRA). Fishbein, M. and Ajzen, I. (1979) state the difference in capacity of attitudes and objectives norms to predict behavioral intention when self-influence is stronger than perceived subjective. The model involved here is the technology acceptance model (TAM). Davis et al. (1989) introduced TAM as an adoption of TRA tailored for user acceptance of information system and provides explanation of the determinants of computer acceptance that is general. The TAM underpinned the study because the study was based on perceived adoption of electronic record management, a transition from manual to automation which the TAM assumption is based on. TAM model is based on four main constructs which suggests that there are a number of factors which influence the individual decisions on the use of new technology and these factors are Perceived usefulness (PU), Perceived ease of use (EU) and Perceived Risk (PR).

However, in as much as the model is being widely used in various technology acceptance studies, there has been no research undertaken using this model specifically in the record keeping and cemetery management in Zambia.

Figure 2 shows TAM model (Source: Venkatesh \& Davis, 2000).

The independent and dependent variables developed in the conceptual framework were used to formulate the hypothesis. The following hypotheses were developed.

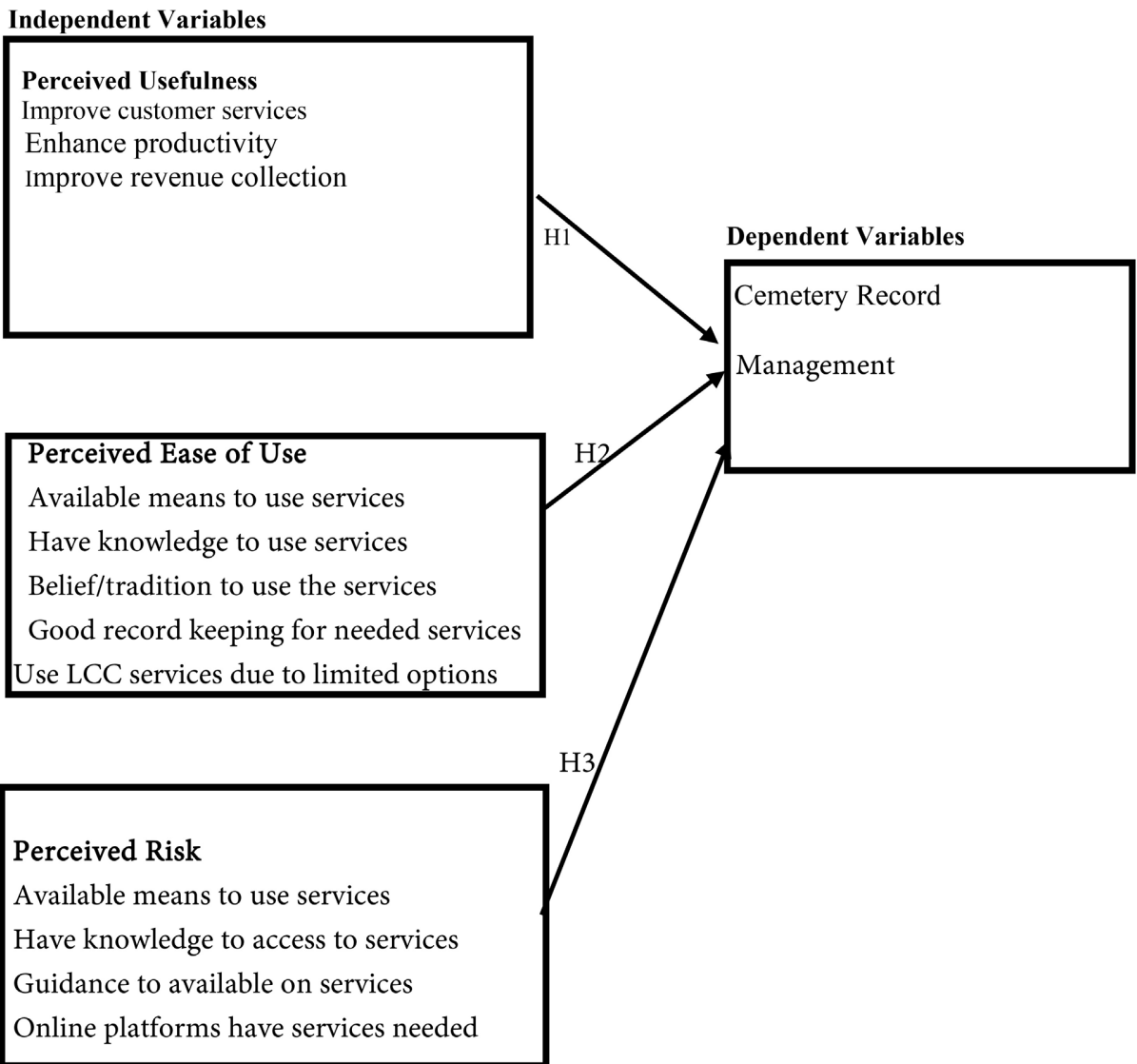

Figure 2. The relationship between independent variables and dependent variables of which the hypothesis was formulated. 


\section{HYPOTHESIS}

\section{Perceived usefulness}

$\mathrm{H}_{1}$ : There is no association between perceived usefulness of the electronic record management and Cemetery management

$\mathrm{H}_{2}$ : There is an association between perceived usefulness of the electronic record management and Cemetery Management.

\section{Perceived ease of use}

$\mathrm{H}_{1}$ : There is no association between perceived ease of use of the electronic record management and Cemetery Management

$\mathrm{H}_{2}$ : There is an association between perceived ease of use of the electronic record management and Cemetery Management

\section{Perceived risks}

$\mathrm{H}_{1}$ : There is no association between perceived risks of electronic record management and Cemetery Management.

$\mathrm{H}_{2}$ : There is no association between perceived risks of electronic record management and Cemetery Management.

\section{Related Gaps (Table 1)}

Table 1. Shows a research gap.

\begin{tabular}{|c|c|c|c|c|c|c|}
\hline Title & Year & Authors & $\begin{array}{l}\text { Conceptual Frame } \\
\text { work }\end{array}$ & Design & Findings & Gaps \\
\hline $\begin{array}{l}\text { 1. Using Archaeological } \\
\text { Methods in Cemetery } \\
\text { Surveys with Emphasis } \\
\text { on the Application of } \\
\text { Lidar }\end{array}$ & 2012 & $\begin{array}{l}\text { Sarah L. } \\
\text { Weitzman }\end{array}$ & $\begin{array}{l}\text { Explicit independent } \\
\text { variables and dependent } \\
\text { variables that is cost } \\
\text { effectiveness, time } \\
\text { efficiency, data accuracy } \\
\text { and quantity of data. }\end{array}$ & $\begin{array}{l}\text { Use of survey methods } \\
\text { Mapping, LiDAR, } \\
\text { Total Station, GPS }\end{array}$ & $\begin{array}{l}\text { The use of LiDAR } \\
\text { scan was not cost } \\
\text { effective. However, } \\
\text { tined to be resourceful } \\
\text { to use in a cemetery } \\
\text { survey. }\end{array}$ & $\begin{array}{l}\text { The study found } \\
\text { that other method } \\
\text { needed to be used } \\
\text { to come up with } \\
\text { effective and } \\
\text { accurate results. }\end{array}$ \\
\hline $\begin{array}{l}\text { 2. Mapping a Community } \\
\text { Cemetery-Collecting } \\
\text { Tangible and Intangible } \\
\text { Heritage Resources }\end{array}$ & 2011 & $\begin{array}{l}\text { Whitney } \\
\text { Goodwin Dr. } \\
\text { Jackson }\end{array}$ & $\begin{array}{l}\text { Independent variables } \\
\text { and dependent } \\
\text { variables that is cost } \\
\text { effectiveness, time } \\
\text { efficiency. }\end{array}$ & $\begin{array}{l}\text { Mapping of the } \\
\text { cemetery using a } \\
\text { compass } \\
\text { Photographic } \\
\text { recording of all } \\
\text { graves, gravestones, } \\
\text { and use of GIS to } \\
\text { make a database. } \\
\text {-Mapping of the } \\
\text { cemetery using a } \\
\text { measuring tape on } \\
\text { family graves }\end{array}$ & $\begin{array}{l}\text { Use of cameras was } \\
\text { effective to capture } \\
\text { the tomb stones }\end{array}$ & $\begin{array}{l}\text { The study found } \\
\text { that mapping need } \\
\text { to be used by using } \\
\text { modern } \\
\text { technologies such } \\
\text { as mobile Apps }\end{array}$ \\
\hline $\begin{array}{l}\text { 3. Using Information } \\
\text { Communication } \\
\text { Technology (ICT) Tools } \\
\text { in Managing Customary } \\
\text { Land, Demarcation, } \\
\text { Conflict and Tenure Data } \\
\text { in Developing Countries: } \\
\text { A Case Study of Zambia }\end{array}$ & 2016 & $\begin{array}{l}\text { Annie } \\
\text { Mporokoso1, } \\
\text { Jackson Phiri }\end{array}$ & $\begin{array}{l}\text { Use of mobile } \\
\text { Application } \\
\text { Architecture (GPS). }\end{array}$ & $\begin{array}{l}\text { A mixed approach of } \\
\text { qualitative and } \\
\text { quantitative survey } \\
\text { methods was } \\
\text { conducted. } \\
\text { Interviews and } \\
\text { questionnaires. }\end{array}$ & $\begin{array}{l}\text { The result of the study } \\
\text { found that land } \\
\text { history and land } \\
\text { administration are } \\
\text { believed to be kept by } \\
\text { people who have } \\
\text { lived longer in the } \\
\text { chiefdom and future } \\
\text { generation. }\end{array}$ & $\begin{array}{l}\text { The study found } \\
\text { that the researcher } \\
\text { only concentrated } \\
\text { on customary land }\end{array}$ \\
\hline
\end{tabular}




\section{Continued}

4. Systems and methods for providing a Database of past life information using a virtual cemetery, 2007 virtual tomb and virtual safe Organizational Paradigm
Shane D. Computer system use Mattaway, of Web cemeteries, web Coral Gables, vaults, web tombs and FL web safes
5. Compacting

Anglo-Saxon cemetery data Research Centre for Computer Archaeology, North Staffordshire

Polytechnic
Mixed approach was Computer system of The study found used by using survey Web safes Web vaults that the computer method, which is for storing web system only qualitative and multimedia concentrated on the quantitative by information mapping and calculating the family associated with lives recording of family tree burial grounds. proved effective. trees
The hard drive used

to store data proved expensive. and dependent variables which is substitution and comparison
Quantitative method A Compaction technique was used in the saving and storage of data
-Hard drive disc space was running out and it was difficult to interpret data held on file
The study concentration was on data management and not data mapping.

\begin{tabular}{ll}
\hline & \\
$\begin{array}{l}\text { 6. E-Cemetery Portal: } \\
\text { A Tool for Digitizing the } \\
\text { Cemetery Culture in } \\
\text { Malaysia }\end{array}$ & $\begin{array}{l}\text { Thien Ee Sien } \\
\text { and Chandra } \\
\text { Reka Rama- } \\
\text { chandiran }\end{array}$
\end{tabular}

RAD is more cost effective compared to

Questionnaires were administered using the user's online form. Use of RAD (Rapid Application Design) and Extreme Programming (XP) model

the and Extreme the portal as well as

Programming (XP) The researcher did model-digitalizing not pay attention the cemetery on the mapping management work and business able to help by using concept. speed up the process of working.

Qualitative-use of Survey methods: mobile phones, Geographical information system (GIS) and ANC Explorer
ANC Explorer gave mismanagement

ANC Explorer provided a good and misguided land mark for the creation $o$ and application business operation cemeteries because it does not provide proper mappings

\begin{tabular}{|c|c|c|c|c|c|c|}
\hline $\begin{array}{l}\text { 8. Mobile Augmented } \\
\text { Reality for Bukit Brown } \\
\text { Cemetery Navigation }\end{array}$ & & $\begin{array}{l}\text { Owen Noel } \\
\text { Newton } \\
\text { Fernando } \\
\text { Chamika } \\
\text { Deshan } \\
\text { Natalie Pang } \\
\text { Ryohei } \\
\text { Nakatsu }\end{array}$ & & $\begin{array}{l}\text { Use of quantitative } \\
\text { and qualitative } \\
\text { method. Clustering } \\
\text { technique was } \\
\text { applied. }\end{array}$ & $\begin{array}{l}\text { The researcher found } \\
\text { that mobile } \\
\text { augmented enable } \\
\text { individual integration }\end{array}$ & $\begin{array}{l}\text { The researcher } \\
\text { could not show that } \\
\text { the graves would be } \\
\text { mapped }\end{array}$ \\
\hline $\begin{array}{l}\text { 9. Historical } \\
\text { Identification and } \\
\text { Mapping }\end{array}$ & 2005 & $\begin{array}{l}\text { Mario } \\
\text { DELAPENA }\end{array}$ & $\begin{array}{l}\text { Use of tables to } \\
\text { illustrate independent } \\
\text { and dependent } \\
\text { variables }\end{array}$ & $\begin{array}{l}\text { Survey methods and } \\
\text { cross section method } \\
\text { was used-Use of } \\
\text { Global position } \\
\text { system (GPS), Digital } \\
\text { cameras }\end{array}$ & $\begin{array}{l}\text { Control of the site } \\
\text { was deemed } \\
\text { necessary to verify } \\
\text { the boundaries of the } \\
\text { portion of cemetery } \\
\text { mapped and observe. } \\
\text { Captured were in the } \\
\text { right area. }\end{array}$ & $\begin{array}{l}\text { The researcher } \\
\text { found that the } \\
\text { mapped cemetery } \\
\text { information could } \\
\text { not be used as a } \\
\text { shared application } \\
\text { medium and } \\
\text { model. }\end{array}$ \\
\hline
\end{tabular}




\section{Continued}

10. Proposal for improving records management practices of 2016 traditional institutions in Ga Molepo, South Africa.

Theoretical frame work

was develop to illustrate the researchers work of relationship between headmen/women which they have with senior leadership

Mahlaga J

The study applied modern landscape

\section{Designing} contemporary landscapes to Solve modern issues in 2010 Higgins. A. J Cemeteries issues of sustainability,

community open space and used Deming and Swaffield's Landscape Architecture Research as a guide model.
Quantitative methods No real records use of cross-sectional management survey and practices were put in not really questionnaires. place considered

\section{The study adopted}

Historical interpretive research methods along with research from secondary sources built a foundation of information to interpret cemetery design development through time.
The study found that mapping was The study found that applying the modern landscape

Use of conventional issues of tools in grave zoning sustainability, are ineffective toward Community open solving contemporary space and respecting land scaping issues. was loosely discussed, hence the need to study this area in detail.
The study made use of thematic approach to interpret qualitative

12. Good Practices in Cemeteries Management 2016 SALGA data and segregate between independent and dependent variables Use of desk survey the macro level, with methods of literature issues such as funding review and interviews and long-term sustainability, and the micro level, in terms of administration and operations. study accompanied by a graphical or visual depiction of the major variables of the study.

\section{affecting records} procurement performance. A case study
13. Assessment of factors management on

\section{OMAE. D.K A conceptual} framework shows the relationship between independent and dependent variable.
The study adopted purposive sampling information procurement officers, communication assistant procurement technology is the first thus, a new study is officers and employees important factor that need that will from accounts affects records address ICT departments who management in technology with participated in the public institutions. tendering process focused on the use of ICT in record management the cause of failures, management and access to services.
The study by Omae, cemetery record

The study revealed that regionally based planning and The researcher was
This study adopted a thematic desktop research, which made use of secondary data. assessment must play too general, did not the dominant role in describe as to considering this land which planning use to balance what tool could best be appears to be emotive used to improve community response planning and to what is an essential effective land use. activity within the

urban fabric. conflicting role of local land regional interests. planning and the
2015 Bennett, P.J. D 


\section{Chapter Summary}

This Chapter highlighted way for effective cemetery management in Zambia and it was presented based on theoretical and empirical reviews in respect to the specific objectives of the research. The literature discussed ancient and modern ways of documentation and record keeping as well as effective record keeping against access to information. The chapter also reviewed documents and theories on the adoption and the use of technology to advance record keeping in cemetery management, highlighting the use of GIS in land mapping and internet and remote sensing along with other advancing technologies. In further highlighted some of the challenges faced by management in ensuring effective cemetery management. Lastly the literature discussed some empirical data from previous studies done similar to this study. The next chapter presented the research methodology.

\section{Methodology}

This chapter highlighted the methods employed in the study by providing a description and explanation of the procedures and methods used in conducting the study. It describes key methodologies such as the study design, population, samples, data collection procedures, analysis and tools utilized and ethical issues. The study used descriptive quantitative approach; the measure for the quantitative approach was nominal by categorizing of responses, and the level of analysis was descriptive (McLeod, 2019). Quantitative study data was presented in the form of statistical representations and interpretations as per the data gathered from the varying sources.

The study was descriptive because it was a survey design using numerical data. The descriptive aspect was the level of analysis because in Surveys, there is no analysis of cause-effect to describe the variables. Sampling design used was Probability sampling used to select the constituencies and a technique called Stratification was used. There were seven constituencies that were stratified for data collection because there are the largest in population size. Constituent samples were picked as follows: firstly, names of all constituencies obtained from Central Statistics Office of Zambia were listed. Secondly the list was further arranged into a cluster of townships/wards with the highly densely populated areas and the lower densely populated areas of Lusaka (Crossman \& Hardesty, 2018).

The target population for this research was Lusaka district with the population of more than 1,733,821 and the Sample design stratified in seven constituencies due to high population density. Taro Yamane formula was applied for a sample size of $400,\left\{n=N / 1+N(e)^{2}\right\}$ to determine the sample. Further, sampling technique used was convenience sampling of adult residents and data collection using researcher led interviews and Questionnaires as a data collation tool. A total of 400 questionnaires were distributed, 313 completed the questionnaires, representing $78 \%$ of the response rate. Primary data was obtained from questionnaires and the interviews while secondary data was obtained from the literature reviewed from similar studies. 
Table 2 shows Lusaka district residential population from Zambia Statistical Agency (Central Statistics Office).

\section{Results and Discussions}

This chapter highlights research results of the study from the descriptive and chi square tests. Results were interpreted using SPSS which then were presented in bar charts, graphs and frequency tables for easy understanding.

Figure 3 shows results on knowledge record keeping. Table 3 shows description, frequencies and percentages distribution. Demographics of the total respondents, $61.7 \%$ were male while $38.3 \%$ were female

Table 2. Total population of Lusaka district residents.

\begin{tabular}{lcc}
\hline & CONSTITUENCY & POPULATION \\
\hline 1 & CHAWAMA & 187,565 \\
2 & KABWATA & 174,323 \\
3 & KANYAMA & 364,655 \\
4 & LUSAKA CENTRAL & 104,979 \\
5 & MANDEVU & 357,538 \\
6 & MATERO & 282,787 \\
7 & MUNALI & 261,975 \\
& TOTAL & $1,733,821$ \\
\hline
\end{tabular}

Table 3. Demographics marital status, education and employment level distribution demographics.

\begin{tabular}{cccc}
\hline \multirow{2}{*}{ Variables } & \multicolumn{3}{c}{ Table of Demographics } \\
\cline { 2 - 4 } Gender & Description & Frequency & Percentage \\
\hline \multirow{4}{*}{ Age } & Male & 193 & 61.7 \\
& Female & 120 & 38.3 \\
\hline \multirow{2}{*}{ Marital status } & 20 or under & 22 & 7.0 \\
& $21-30$ & 67 & 21.4 \\
& $31-40$ & 67 & 42.2 \\
& $41-50$ & 132 & 19.8 \\
& $51-60$ & 14 & 4.5 \\
& $61+$ & 16 & 5.1 \\
\hline \multirow{3}{*}{ Education Level } & Married & 188 & 60.1 \\
& Divorced & 17 & 5.6 \\
& SHS and below & 50 & 16.8 \\
& Diploma & 122 & 39 \\
& First Degree & 74 & 23.6 \\
& Masters & 49 & 15.7 \\
& PHD & 13 & 4.2 \\
\hline \multirow{2}{*}{ Employment Status } & Not working & 73 & 23 \\
& Self-employed & 108 & 13.8 \\
& Salaried worker & 114 & 36.4 \\
& Pensioner & 18 & 5.8 \\
\hline
\end{tabular}


Knowledge about record keeping and management; 34\% said good, $20 \%$ said moderate, $27 \%$ said very good, 125 said very poor and $7 \%$ said poor.

Pearson Chi-Square Test (234.7) showed that the probability value is 0.260 which is more 0.05 indicating lack of statistically significant relationship between the variables. Therefore, there is no enough evidence to reject the null hypothesis that perceived usefulness of electronic data management of records would affect access of cemetery services at the Lusaka City Council.

1) Shows the adoption results analysis (Table 4).

2) Shows the chi-square test (Table 5).

Table 5 shows the Pearson Chi-Square test (169.7) indicated that the probability value of 0.01 indicates a statistically significant association between adoption of electronic management data and access to services at Lusaka City Council. Therefore, the null hypothesis was rejected.

3) Pearson chi-square on risk performance (Table 6).

Table 6 shows Pearson Chi-Square test (753.0) indicated that the probability value of 0.01 which is less than 0.05 , which is a statistically significant perceived risks of electronic record management and Cemetery Management. Therefore,

\section{Very poor Poor Moderate Good Very good}

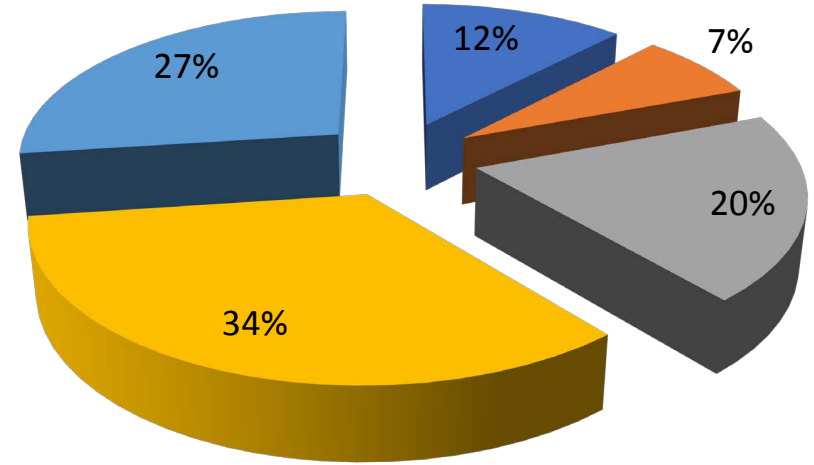

Figure 3. Results about knowledge record keeping based on technology acceptance model (TAM).

Table 4. Shows the adoption results analysis.

\begin{tabular}{|c|c|c|c|c|c|c|c|}
\hline \multirow{2}{*}{\multicolumn{2}{|c|}{ Variables }} & \multicolumn{5}{|c|}{ Access to services at LCC } & \multirow{2}{*}{ Total } \\
\hline & & Strongly Disagree & Disagree & Neutral & Agree & Strongly agree & \\
\hline \multirow{4}{*}{$\begin{array}{l}\text { Adoption of electronic } \\
\text { management of data }\end{array}$} & Disagree & 0 & 9 & 0 & 0 & 0 & 9 \\
\hline & Neutral & 0 & 22 & 26 & 35 & 0 & 83 \\
\hline & Agree & 31 & 119 & 34 & 13 & 5 & 202 \\
\hline & Strongly agree & 0 & 0 & 5 & 13 & 9 & 27 \\
\hline \multicolumn{2}{|l|}{ Total } & 31 & 150 & 65 & 61 & 14 & 321 \\
\hline
\end{tabular}

Source: Primary Survey (2020). Shows results by the respondents on access to services at LCC. 
Table 5. Shows the chi-Square test.

\begin{tabular}{ccccc}
\hline $\begin{array}{c}\text { Efforts expectancy } \\
\text { on record keeping } \\
\text { adoption factors }\end{array}$ & $\begin{array}{c}\text { I think accessing } \\
\text { information is easy and } \\
\text { effective at LCC }\end{array}$ & $\begin{array}{c}\text { I think it is easy to get services } \\
\text { at LCC due to good record } \\
\text { keeping management system }\end{array}$ & $\begin{array}{c}\text { I find it easy to use } \\
\text { information at LCC }\end{array}$ & $\begin{array}{c}\text { I think of record keeping } \\
\text { and cemetery management } \\
\text { to be effective }\end{array}$ \\
\hline $\begin{array}{c}\text { Respondents } \\
\text { Median }\end{array}$ & 301 & 301 & 301 & 300 \\
Mode & 3 & 3 & 2 & 3 \\
\hline
\end{tabular}

$1=$ Strongly Disagree; 2 = Disagree; 3 =Neutral; 4 = Agree and 5 = Strongly Agree. Source: Primary Survey (2021) Response results from respondents on Chi-Square test on effort expectancy on record keeping adoption factors.

Table 6. Pearson chi-Square on risk performance.

\begin{tabular}{ccccc}
\hline $\begin{array}{c}\text { Performance } \\
\text { expectancy on } \\
\text { record keeping } \\
\text { adoption factors }\end{array}$ & $\begin{array}{c}\text { Record keeping management } \\
\text { would be useful in ensuring } \\
\text { LCC efficiency on carrying } \\
\text { on Tasks }\end{array}$ & $\begin{array}{c}\text { I think adopting electronic } \\
\text { record keeping would } \\
\text { improve customer service and } \\
\text { efficiency delivery at LCC }\end{array}$ & $\begin{array}{c}\text { I think using } \\
\text { electronic record } \\
\text { keeping would } \\
\text { enhance productivity }\end{array}$ & $\begin{array}{c}\text { I think using record keeping } \\
\text { improve performance and } \\
\text { revenue collection }\end{array}$ \\
\hline $\begin{array}{c}\text { Respondents } \\
\text { Median }\end{array}$ & 313 & 313 & 313 & 313 \\
Mode & 4 & 4 & 4 & 4 \\
\hline
\end{tabular}

1 = strongly disagree; 2 = Disagree; 3 = Neutral; 4 = Agree; and 5 = Strongly Agree. Source: Primary Survey (2021). Respondent results on risk performance.

the null hypothesis is rejected and conclude that there was an association between perceived risks of electronic record management and Cemetery Management.

\section{Conclusion}

These results show that although the perceived usefulness would encourage the use of electronic management of records and access, the perceived ease to use and risks would affect access. This is because the majority have knowledge of record management but due to manual recording of data, cemetery management and storing of data is not effective. The study concluded that the public has challenges accessing the cemeteries. It was also concluded that the mapping and cemetery record keeping was poor making it very difficult for family members to locate the tomb stones of their departed family members.

\section{Recommendations}

The study recommends that, the Lusaka District City Council should migrate from manual record management to the electronic management of cemetery records since the perceived usefulness of the public supports electronic management. The study should have included more rural sites of Lusaka province to include perception of more digitally divided areas. Therefore, future studies must look at the perception and experiences of rural areas of Lusaka Province 
and councils in the country at large.

\section{Limitations of the Study}

This study was restricted to Lusaka residents only leaving out other districts councils in Zambia which would have given a broader view of record keeping and cemetery management of all municipal managed cemeteries from different districts. The other limitations were limited interactions with the public due to the high case of the COVID-19 pandemic which affected most of the townships in Zambia.

\section{Rationale of the Study}

Considering the findings of this study as well as limitations highlighted some further research should be carried out in order to gain a deeper insight into the topic. Further studies could include:

A study can be undertaken to cover other regions other than, Zambia to the other parts of the African region to understand if the results are applicable across Africa. A mixed method study approach can be selected for future research as current research has made use of a quantitative approach and the results may be limited. Using a similar research structure, the research can be done using other technology models and theories.

\section{Acknowledgements}

The authors wish to acknowledge the valuable contribution of the participants who took part in the study.

\section{Conflicts of Interest}

The authors declare no conflict of interest with regard to the publication of this journal.

\section{References}

Afla, M., \& Reza, M. (2012). Sustainability of Urban Cemeteries and the Transformation of Malay Burial Practices in Kuala Lumpur Metropolitan Region. International Journal of Social, Behavioral, Educational, Economic, Business and Industrial Engineering, 6, 808-829.

Crossman, K. A., \& Hardesty, J. L. (2018). Placing Coercive Control at the Center: What Are the Processes of Coercive Control and What Makes Control Coercive? Psychology of Violence, 8, 196-206. https://doi.org/10.1037/vio0000094

Davis, F. D., Bagozzi, R. P., \& Warshaw, P. R. (1989). User Acceptance of Computer Technology: A Comparison of Two Theoretical Models. Management Science, 35, 982-1003. https://doi.org/10.1287/mnsc.35.8.982

Fishbein, M., \& Ajzen, I. (1979). Belief, Attitude, Intention, and Behavior: An Introduction to Theory and Research. Addison-Wesley.

Fishbein, M., \& Ajzen, I. (1979). Belief, Attitude, Intention, and Behavior: An Introduction to Theory and Research. Addison-Wesley. 
Grzybowski, A. (2012). "Land and Conflict: Toolkit and Guidance for Preventing and Managing Land and Natural Resources Conflict. UN Department Of political Affairs.

Komalasari, R. (2020). The Wagf Cemetery Information System. Materials Science and Engineering, 879, Article ID: 012035.

Koonce, C. (2011). Cemeteries in the Urban Plan: Opportunities and Constraints. University of Georgia.

McLeod, S. A. (2019, July 30). Qualitative vs. Quantitative Research. Simply Psychology. http://www.simplypsychology.org/qualitative-quantitative.html

Mporokoso, A., \& Phiri, J. (2016). Using Information Communication Technology (ICT) Tools in Managing Customary Land, Demarcation, Conflict and Tenure Data in Developing Countries: A Case Study of Zambia. IJCSMC, 5, 594-603.

Ngoepe, M. (2014). The Role of Records Management as a Tool to Identify Risks in the Public Sector in South Africa. South African Journal of Information Management, 16, 1-8. https://doi.org/10.4102/sajim.v16i1.615

Phiri, P. (2015). Cemetery Space Runs Low in Zambia as Residents Reject Cremation on Religious Grounds.

https://globalpressjournal.com/africa/zambia/cemetery-space-runs-low-in-zambia-as-r esidents-reject-cremation-on-religious-grounds/

Venkatesh, V., \& Davis, F. D. (2000). A Theoretical Extension of the Technology Acceptance Model: Four Longitudinal Field Studies. Management Science, 46, 186-204. https://doi.org/10.1287/mnsc.46.2.186.11926

Weitman, S. L. (2012). Using Archaeological Methods in Cemetery Surveys with Emphasis on the Application of Lidar. Electronic Theses and Dissertations. 627. https://digitalcommons.georgiasouthern.edu/etd/627 